Прегледни чланак

341.232:325]:061.1EU

doi:10.5937/zrpfns53-18819

Nenad Z. Stekić, Research Assistant

Institute of International Politics and Economics

nenad.stekic@diplomacy.bg.ac.rs

\title{
EXTREMISM AS A FACTOR OF SYSTEMIC DYNAMICS OF COMMON SECURITY AND DEFENSE POLICY DURING THE MIGRATORY CRISIS ${ }^{1}$
}

\begin{abstract}
This paper aims at explaining causes of key changes of European Union's Common Security and Defense Policy (EU CSDP) characteristics as a reference object in relation to the five-year influx of migrants to the EU between 2013 and 2017. Author casts his assumption according to which the measurable outcome of a large wave of migrants from the Middle East and North Africa to Europe, as well as phenomena such as terrorist and other extremist acts, significantly influence and alter the nature of this supranational policy. Based on theoretical debates about forced migration, the author deployed a relatively new concept of regional humanitarian identity, which is based on norms and values of particular hosting states. The overall performance of the subdivisions of the region - the state, their institutions, and citizens - is conditioned by internal norms that arise as a result of traditional and cultural factors. Analytical and systematic presentation of the conceptual model identified numerous variables whose interactions significantly influence the functioning of a complex system such as the EU CSDP. After having applied systemic dynamics approach, author concludes that by changing the European Union's regional humanitarian identity, a precondition for normative and institutional change of this policy was also made possible.
\end{abstract}

Keywords: regional humanitarian identity, CSDP, CFSP, migrations, MENA region, systemic dynamics.

${ }^{1}$ The article was realised within the project: "Serbia in contemporary international relations: Strategic directions of development and consolidating the position of Serbia in international integrative processes - foreign affairs, international economic, legal and security aspects", Ministry of Education and Science of the Republic of Serbia, no. 179029 (2011-2019). 


\section{INTRODUCTORY NOTES}

The Common Security and Defense (hereinafter CSDP) is an integral part of the Common Foreign and Security Policy (CFSP), and as such presents a unique type of integration in the sphere of defense and security in the world. Established at the European Council Summit in Saint Malo in 1999, as the "European Security and Defense Policy", since the Lisbon Treaty entered into force in December 2009, this policy is renamed into Common Security and Defense Policy of the European Union (EU CSDP). The tracking of its genesis can best be complied through the elements that make its integral part, as well as the elements gradually being added under its umbrella. Currently, this policy consists of 10 elements, although some scholarly views count 11 of them. ${ }^{2}$

The largest number of academic community's dealing with CSDP research agrees upon that it's most visible and most important element are crisis management operations, or civilian missions and military operations. ${ }^{3}$ Through these mechanisms, the European Union is trying, in the global context, to obtain a global player title, through promotion of global leadership concept. Bearing in mind that the CSDP (still) does not represent a substitute for the joint military forces of the European Union, military operations also contribute to further defense integration at the supranational level. For now, this is the only possible way of engaging national member states' contingents outside the European Union. The basic specificity of participation in military operations, following the Lisbon Treaty, is the possibility of participating in military operations by armed forces of EU candidate countries. A similar situation exists with the countries in the Western Balkans region, each of which participates not only in military operations, but also in European Union civilian missions around the world. ${ }^{4}$ In addition, both Turkey and Canada actively participate in crisis management operations. Article 44 of the Lisbon Treaty provides for the possibility that several EU Member States can independently create and transmit military operations under the flag of the European Union. ${ }^{5}$ Article 44 does not represent a qualitatively new form of participation in multinational operations, but it only facilitates the participation of several member

${ }^{2}$ The CSDP elements are: disarmament, prohibition of the proliferation and proliferation of weapons of mass destruction, the maritime security, the sanctions policy, the fight against pirates, crisis management operations, crisis response, conflict prevention, and Instrument for stability. In some respects, crisis management operations are broken down into civilian missions and military operations, as in two separate parts of the policy. More on CSDP elements: https://eeas.europa.eu/ headquarters/headquarters-homepage/area/security-and-defence_en (Accessed on: 4.4.2018, 14:32)

${ }^{3}$ Official website of the EEAS, available at: https://eeas.europa.eu/topics/common-securityand-defence-policy-csdp_en, (Accessed on: 11.06.2018, 15:56)

${ }^{4}$ Ibid.

${ }^{5}$ Ibid. 
states in case of urgency and existence of a lack of consensus regarding the deployment of the operation. Through these mechanisms, European Union tries to become so-called "Global player" and thus to promote a concept of "global leadership". With no existing military capabilities at the supranational level, it is clear that the officials of this state-of-the-art creation are trying to project the national interests of their states by using the only existing mode of providing such interests, which can be achieved through this policy. The institutional structure of CSDP is extremely complex (see Scheme 1). The prevailing viewpoints for analytical needs, point to the consideration of CSDP institutions in several different levels. At supranational level, European Union bodies in the area of defense and security are differentiated into three subgroups: strategic, operational and tactical.

The first one includes the EU's largest institutions, while the Political-Security Committee, the Military Committee (as a subcommittee of the previous one), the Committee on Civilian Aspects of Crisis Management (CIVCOM), and the Center for EU Operations operate on the operational and supranational level. ${ }^{6}$ Tactical level is occupied by certain working bodies and groups within the mentioned structures and institutions. ${ }^{7}$ At the national level differentiation is not so complex, considering that the working bodies and representatives of the defense ministries, and those in charge of foreign affairs and internal affairs are in charge of security and defense issues. This paper seeks to show the most significant theoretical views on migration studies, as well as to inspect contribution of pull \& push mechanism/concept to migratory flows towards the EU Member States. Thus, it aims at identifying variables that contribute to the development of extremism and radicalism in Europe and in that sense significantly affect the systemic dynamics of the CSDP.

The scientific goal of exploring the interrelation between the change of basic policy characteristics as a reference object in relation to the five-year migration flow into the European Union was applied for the period 2013-2017. The application of the system dynamics model will provide an important basis for understanding the change of nature, the way it operates and develop this policy. For this migratory period, the author will offer vector directions among the identified variables, or key extremist and terrorist events that might have led to the change of the security and defense paradigm of the European Union. In the first part of the article, author presents the development and key elements of the EU CSDP as the reference object of the examination. The intention of the author is to present development and

\footnotetext{
${ }^{6}$ Weiler Kathleen, European constitutionalism beyond the state, Cambridge University Press, 2003.

${ }^{7}$ Such spots for instace are taken by the Logistical department, Situational Centre, counsellor groups, and the COREPERs, as the permanent representative body of Military Committee and Political-Security Committee. More available at: https://eeas.europa.eu/headquarters/headquartershomepage/area/security-and-defence_en (Accessed on: 4.6.2018. 15:13)
} 
key CSDP elements as a reference object. The intention of the author is to determine whether and under what conditions a change in the functioning and development of CSDP is possible, in the case of simulating all variables that do not (indirectly) contribute to the policy change, and to the rise of violent extremism in Europe.

\section{CONCEPTUALISATION OF MIGRATION STUDIES}

According to Giovanna Zincone and Tiziana Caponio, the development of studies in the field of migration has been underway in several different waves. The first generation of studies was essentially interested in the demographic composition and the evolution of migratory waves into European countries. While the second generation of research was primarily focused on the economic integration of immigrants and their social behavior, the third generation was based on integration policies and political participation of immigrants. ${ }^{8}$ The last generation has touched on issues and problems of understanding the way immigrants and immigration policies are adopted and adopted. More recently, the new generation is striving to conduct research on multi-level governance policies related to immigrants, but also to immigration in general. ${ }^{9}$ These consequences of migrant waves are mostly far-reaching, and in particular, they are visible from the "most recent" which began in 2013. Zinkone and Caponio cite several factors that, as they claim, are highly variable, varying degrees of migration studies within European countries.

The main ones are the maturity and development of public policies in political science, in various countries. ${ }^{10}$ These authors also state that migration studies in Austria developed only during the 1980s, while they later developed in Germany and Sweden, and then in the academic work of authors from the Mediterranean countries. ${ }^{11}$ The response of the state (or group of countries) to the housing of non-residents in its territories is a central thesis in the development of contemporary academic debates on migration and extremism. Edward J. Newman begins an analysis of the current scientific thematization of European humanitarian practices, offering the concept of "regional humanitarian identity". ${ }^{12}$ In article published in 2018 "The Limits of Liberal Humanitarianism in Europe: Responsibility for Protection and Forced Migration", Newman points to the values on which the modern European Union rests. These values represent a prerequisite and determining the element on which European humanitarian practice rests.

\footnotetext{
${ }^{8}$ Zincone, Giovanna \& Tiziana Caponio, "The Multilevel Governance of Migration", The Dynamics of International Migration and Settlement in Europe, 2006, p.269.

${ }^{9}$ Ibid.

${ }^{10}$ Ibid.

${ }^{11}$ Ibid., p. 206.

${ }^{12}$ Newman, Edward, "The Limits of Liberal Humanitarianism in Europe: The 'Responsibility to Protect' and Forced Migration”, European Review of International Studies, 2018, p.5.
} 
Furthermore, he claims that some authors rightfully question the legitimacy of this concept, because of great discrepancy between normative principles and foreign policy demonstrated by the European Union. ${ }^{13}$ The EU Global Strategy from 2016 proclaims that

"...in preserving the quality of democracy, the European Union respects national, European and international law in all spheres, from migration and asylum, through energy, and the fight against terrorism. Resigning these values is a matter of law, but also of ethics and of our identity."14

Key critiques relate to the fact that the European Union's norms are more important in situations where the CSDP does not oppose different normative frameworks (such as cooperation with democratic states), as well as when the European Union conducts its relations with relatively weak countries and regions. ${ }^{15}$ Newman acknowledges that the normative concept of regional humanitarian identity is still largely based on the credibility enjoyed by the European Union in the global arena, or, as this author calls, "moral leadership" and commitment to the principle of responsibility to protect. ${ }^{16}$ Changing the regional humanitarian identity inducts the direction of action and acts of political entities such as states and international organizations.

\subsection{Pull and Push factors}

According to classical pull \& push formulations, potential migrant weights negative trends which push him/her out of domicile country (low wages, low living standards, bad working conditions etc.) to the positive factors and wellbeing which they could consume in the destination country. In this case, the decision to migrate is led by conditions that can be obtained in destination state. ${ }^{17}$

Rejection and attraction model implies a static perspective of study, focusing on external factors as the main drivers of migration. Thus, it is unable to analyze migration, as it went through a transformation, which in turn diminished its scientific value. ${ }^{18}$ Sriskandarajah et al., claim that in terms of migration studies, the

13 Ibid.

${ }^{14}$ Global Strategy of the European Union, Official EU Journal, Brussels, 2016.

${ }^{15}$ Ian Manners, Normative Power Europe: A Contradiction in Terms?, 2002, Journal of Common Market Studies,Vol.40, No.2

${ }^{16}$ Newman, Edward, "The Limits of Liberal Humanitarianism in Europe: The 'Responsibility to Protect' and Forced Migration", European Review of International Studies, 2018, p.5.

${ }^{17}$ For more on theoretical and operational inputs and determinants of the pull-push factors, consult: Schoorl, Heering et al., "Push and pull factors of international migration: a comparative report”, European Communities, Luxembourg, 2000.

${ }^{18}$ De Haas, H., "The myth of invasion: The inconvenient realities of African migration to Europe", Third world quarterly, 2008, 29(7) 
pull \& push factors failed to provide any reasonable responses to the most basic issues, as well as to the visibility of reactions by the national state..$^{19}$ Certainly, recent academic literature is saturated with discussions about the reaction of a particular entity in relation to immigrants. Intending to determine what precedes the response (response) of the country of residence, Everett Lee identified four groups of factors that influence the decision to migrate: factors related to the area of origin; factors related to the destination area; possible obstacles of migration between areas of origin and destination, (such as distance, physical barriers, immigration laws, and others); and personal factors of migrants themselves which modify other factors in terms of decision to migrate. ${ }^{20} \mathrm{On}$ this trail, Douglas Massey and his associates developed their argument about the pull and push factors.

They believe that migration is not triggered by push factors in countries of origin (low wages or high unemployment), but by attracting factors (pull factors) in destination countries. ${ }^{21}$ Economically highly developed countries produce the so-called division of the labour market structure, securitized well-paid jobs sector, as well as a managerial, or socially highly-valued position, is created on the one hand, and on the other, a sector with insecure, poorly paid and low-value jobs - in the literature these jobs are popularly called 3D - dirty, dangerous and difficult. ${ }^{22}$ The factors of attraction and suppression do not necessarily have to be categorized, nor are their classification generally accepted. However, certain authors claim that it is possible to create a pull \& push factor matrix for each individual case, making them essentially sui generis. In this sense, Martin and Zurker propose an analytical matrix of factors that can be useful in studying migratory movements.

Table 1. Migration targeting factors

\begin{tabular}{c|c|c|c}
\hline $\begin{array}{c}\text { Migration } \\
\text { type }\end{array}$ & $\boldsymbol{P u l l \text { factors }}$ & $\boldsymbol{P u s h \text { factors }}$ & Networking/other \\
\hline Economic & $\begin{array}{c}\text { Labour force } \\
\text { recruitment }\end{array}$ & $\begin{array}{c}\text { Unemployment or } \\
\text { low salary level }\end{array}$ & $\begin{array}{c}\text { Jobs and salaries } \\
\text { information }\end{array}$ \\
\hline $\begin{array}{c}\text { Non- } \\
\text { economic }\end{array}$ & $\begin{array}{c}\text { Personal moments } \\
\text { (family reunion) }\end{array}$ & $\begin{array}{c}\text { War, civil war, any other } \\
\text { type of international } \\
\text { or domestic violence }\end{array}$ & $\begin{array}{c}\text { Communication, } \\
\text { transportation, new } \\
\text { experiences willingness }\end{array}$ \\
\hline
\end{tabular}

Source: Martin, P. \& G. Zurcher (2008). Managing Migration: The Global Challenge.

${ }^{19}$ Sriskandarajah, Dhananjayan, Laurence Cooley, and Howard Reed, "Paying their way: The fiscal contribution of immigrants in the UK", Institute for Public Policy Research, London, 2005. p.1.

${ }^{20}$ Lee, Evans, "A theory of migration", Demography, 1966, 3(1), p.47-57.

${ }^{21}$ Massey, Douglas et al., "Theories of international migration: A review and appraisal", Population and development review, 1993, pp.431-466.

${ }^{22}$ Ibid. 
Based on the distinction shown in Table 1, it is possible to determine the pull $\&$ push migration factors that can contribute to the development of extremism in Europe. Such outcome factors come from both migratory geo spaces - the MENA region ${ }^{23}$ and Europe. ${ }^{24}$ With respect to the postulate of pull \& push concept, according to which they exist in the area of emigration and immigration, Table 2 presents modified migration factors that can be characteristic in the context of extremism.

Table 2. Modified migratory factors potentially causing more violent behaviour

\begin{tabular}{|c|c|c|c|c|}
\hline Region & Pull factors & & Push factors & Catalytic factors \\
\hline MENA & $\begin{array}{l}\text { - Sporadic ceasefire } \\
\text { - Permanent } \\
\text { international } \\
\text { humanitarian } \\
\text { help } \\
\end{array}$ & \multicolumn{2}{|c|}{$\begin{array}{l}\text { - Conflicts and Civil Wars } \\
\text { - Repressive political regimes } \\
\text { - Endangered individual security } \\
\text { - Devastated settlements and } \\
\text { urban conurbations }\end{array}$} & $\begin{array}{l}\text { - Forced migratory } \\
\text { flows } \\
\text { - Group flows; } \\
\text { displaced family } \\
\text { members }\end{array}$ \\
\hline & \multicolumn{4}{|c|}{ Massey et al. } \\
\hline CSDP & \multicolumn{2}{|c|}{$\begin{array}{l}\text { Democratic and } \\
\text { normative "regional } \\
\text { humanitarian identity" } \\
\text { of the EU } \\
\text { • „Forced quality“ of living } \\
\text { conditions in the EU }\end{array}$} & $\begin{array}{l}\text { - Creation of "no-go" } \\
\text { zones } \\
\text { - Local populations } \\
\text { aversions } \\
\text { - Religious and political } \\
\text { freedoms }\end{array}$ & $\begin{array}{l}\text { - Immigrants' camps } \\
\text { and settlements } \\
\text { - Ghettoization of } \\
\text { Western Europe's } \\
\text { cities }\end{array}$ \\
\hline
\end{tabular}

Source: Compiled by author

The classical classification of economic and non-economic migration factors in the analytical matrix has now being replaced by the geographic regions of a concrete case study. The area of emigration is, as previously mentioned, the MENA region, while the inflow area is migration (Western) Europe, that is, the European Union. Presenting the findings of a survey conducted in several countries (France, Germany and Switzerland), on a representative sample of 2,400 respondents, Friedrich Heckmann points to several types of integration of descendants of the first generation of immigrants. It is important to note that the survey was carried out in 2004 and that immigrants entered the sample from the territory of Turkey, the former Yugoslavia, the Maghreb, and Portugal. Heckmann defines cultural integration as a complex and heterogeneous area that relates to beliefs

${ }^{23}$ The MENA region (Middle East and Northern Africa) is a vast geospace of the North Africa and the Middle East. According to some figures of the UNHCR, number of illegal migrants has reached 60 millions by the end of 2014, which is the second largest migration flow ever since the Second World War occurred (The New York Times, 2015).

${ }^{24}$ Under "Europe" in terms of this paper, author shall observe the EU without Great Britain and Denmark, both having opted out from the militarily segments of the CFSP. 
and values, cultural competences, practiced pop culture, and everyday's behaviour. ${ }^{25}$ Likewise, social integration is determined as interpersonal interactions and membership in associations. ${ }^{26}$ Findings from his research indicate a reduced level of tolerance for the local population in all three countries in terms of accepting immigrants and even their descendants. As the main determinant of structural integration, Hackmann lists the acquisition of rights and access to positions, or status in key institutions of the society. He believes that structural integration is a two-way process that involves the desire of both sides (local population and immigrants) to inclusion in social flows, while it also includes identification integration that is reflected in the sense of belonging and identification in the broader sense. ${ }^{27}$ In the end, this author identifies functional integration, arguing that there is "a justified need for immigrants in different sectors of the economy in relation to their peculiarities". ${ }^{28}$

\section{SYSTEMIC DYNAMICS OF THE EU CSDP IN MIGRATORY CRISIS}

As it was initially emphasized, CSDP is a subpart of the CFSP system, and an extremely complex system consisting of several elements, which are the product of a much more complex of decision making process, cooperation, negotiation, as well as interactions with other entities, countries, international organizations and other important international bodies. In this sense, this policy represents a fruitful reference object for the application of system dynamics, with extensive academic discussion regarding its realization and interpretation. System dynamics allows the analysis of migratory phenomena by including the qualitative and quantitative variables that influence and determine it. ${ }^{29}$ The interest in system dynamics came about when it was understood that it could uniquely contribute to the presentation of the real world. Jay W. Forrester warns that dynamics can show the non-linearity, complexity, and return effects inherent in the study of social and physical phenomena. ${ }^{30}$ Thomas Gehring \& Benjamin Faud in their article "Dynamics of complex systems: micro-based and systemic effects" pointed to the theo-

${ }^{25}$ Heckman, Friedrich, "National modes of immigrant integration", Comparative European Research in Migration, Diversity and Identities University of Duesto, Bilbao, 2005

${ }^{26}$ Ibid., p.106.

${ }^{27}$ Ibid.

${ }^{28}$ Ibid.

${ }^{29}$ Ninković V. et al., "Dynamic Migration Flow Modeling”, Security Dialogues, Vol 8, No.1-2. Skopje: St. Cyril and Methodius University, pp.149-169

${ }^{30}$ Forrester, J. "System dynamics, systems thinking, and soft OR", System dynamics review, 1994, Vol.10 (2-3), 245-256 
retical void in terms of the functioning of complex systems, made up of several sides. $^{31}$

They argue that as long as there is a sincere interest in co-operation between a large number of stakeholders delegating the system, there is a great chance that the interaction between the institutional elements can be transferred from the state of an open conflict to the state of a well-regulated "labour division". Such division of labour always assigns clearly defined roles, and the efficient functioning of the system..$^{32}$ They further state that at the level of the units of the system of international relations - the state, they are just superpowers, which influence the development (or, on the other hand, the disabling) of a particular system. In the case of the EU CSDP, these were the United States, which first promoted security and defense cooperation among EU Member States, and now it is disabling. ${ }^{33}$ They suggest managing complex regimes as an adequate term for centralizing system management. Therefore, in order to understand the complexity of this policy, it is necessary to point out the normative and institutional differentiation of the EU CSDP.

Table 3. Normative and institutional differentiation of the EU CSDP

\begin{tabular}{|c|c|c|}
\hline Level & Normative & Institutional \\
\hline MACRO & $\begin{array}{l}\text { Lisbon Treaty } \\
\text { EU Global Strategy (2016), } \\
\text { Strategic decision making } \\
\text { process }\end{array}$ & $\begin{array}{l}\text { European Commission (EEAS) } \\
\text { EU High Representative/EU Commission } \\
\text { Vice President }\end{array}$ \\
\hline MESO & \begin{tabular}{|l|} 
Strategic \& operational \\
decisions of the Council of \\
Ministers, Politico-Security \\
Committee and of the Military \\
Committee
\end{tabular} & $\begin{array}{l}\text { Directorates General (DGs) } \\
\text { Politico-Security Committee (Military } \\
\text { Committee) } \\
\text { Politico-military group and Civil Planning } \\
\text { Committee } \\
\end{array}$ \\
\hline MICRO & \begin{tabular}{|l|} 
Regulations, acts, operational \\
plans, crisis management plans, \\
tasks and other legislation \\
proposals coming from the EU \\
institutional elements
\end{tabular} & $\begin{array}{l}\text { - European Security and Defence College } \\
\text { - European Situation / Satellite Center / EDA } \\
\text { - Diplomatic representatives of the EU } \\
\text { - European Institute for Security Policy } \\
\text { - Multi sector working groups / units within } \\
\text { the EEAS }\end{array}$ \\
\hline
\end{tabular}

Source: Author

${ }^{31}$ Gehring, Thomas and Benjamin Faude, "The dynamics of regime complexes: Microfoundations and systemic effects", Global Governance: A Review of Multilateralism and International Organizations, 2013, 19, no. 1, 119-130

${ }^{32}$ Ibid., p. 127

${ }^{33}$ Ibid., p.128 
They believe that in a system where there is no central management, it is necessary to establish secretariats through which decisions will be made, in the absence of an organizational center. ${ }^{34}$ Forester's idea builds upon the previous arguments, as it points to the necessity of validating models that simulate changes in the policies of complex entities such as the European Union. ${ }^{35}$ In their article "System Dynamics of Problem Solving to Improve the Condition", these authors suggest seven steps characteristic of changing the state of a particular entity/policy: describing the system, simulating the model, designing alternative policies, education and debate, and finally, the implementation of changes in policies and structures. ${ }^{36}$ In such a matrix, the simulation of feedback model is the most appropriate tool by which it is possible to "measure" the CSDP's efficiency and operation. Namely, the return matrix could even be adequate for presenting, and establishing new variables and factors in further study of the development of CSDP elements. In this sense, in finding an adequate model it is necessary to present the CSDP functioning from a holistic perspective. If Member States do not have a consensus on the most important issues related to the EU CSDP, then institutions and regulatory bodies will function significantly more inadequately or inconsistently.

Therefore, the effect of the Member States on the CSDP is direct, but this process is two-tailed as in case of CSDP and Member States relations. In the holistic perspective of CSDP, external factors have a direct two-tailed effect on the mentioned policy, unlike the CFSP, with which they are associated with a weaker connection without clear vector directions, since the latter policy is an indirect link to the CSDP. Beside holistic approach, CSDP can be seen as a model that can be systemically simulated and bottom-up approach.

Scheme 3. Bottom-up approach in migratory crisis of the CSDP

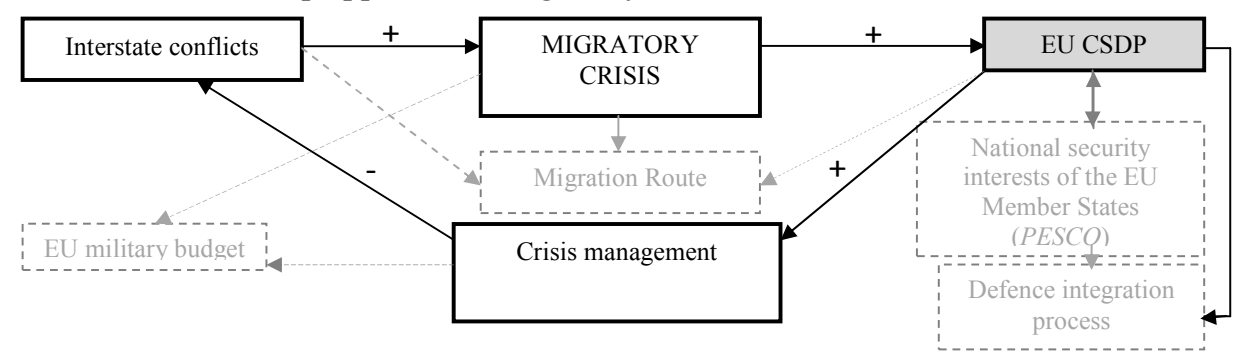

Source: Author, adapted scheme

\footnotetext{
${ }^{34}$ Ibid., p. 128

${ }^{35}$ Op.cit. Forrester, J. "System dynamics, systems thinking, and soft OR", p.104

${ }^{36}$ Ibid.
} 
It is clear that the model of return action is incomplete, and represents only the starting point for further studies of CSDP in application to a specific migratory crisis. Stronger defense integrations in the Old Continent can be seen through analysis of its qualitative features, as a variable that is significant in modern European security architecture. Thus, in the broadest sense the migratory crisis and problems on the route have a balancing effect on CSDP. The CSDP military budget is increasing dramatically from year to year, ${ }^{37}$ so it has a stabilizing effect on the security of financing (and survival) of crisis management operations. They largely determine the amount of the overall budget of the CSDP (nearly $80 \%$ ), but at the same time point to the needs for budget trends for the coming period in line with the needs on the ground. ${ }^{38}$ Also, operations ensure the assertiveness of the European Union and the status of a "global player" in the international arena. The intensity, but also the number of armed conflicts, has a stabilizing effect on the quality, mandate and number of members in operations/missions. An essential feature is the interests of Member States, which do not always match all security issues. Countries also participate in the decision to establish missions/operations, as well as the degree of integration in the security and defense sphere, thus influencing the further defense integrations within the European Union. Implication tests of a particular policy according to Senge and Forrester consist of system improvement tests, predictions in behavioral changes, marginal adequacy, and policy sensitivity. ${ }^{39}$ Following the logic of the previously presented system dynamics matrix, after modelling, it is necessary to design alternative policies and structures. The European Union, as a complex decision-making mechanism, very difficultly adopts acts at a strategic level, as it requires the consent of all Member States (in the case of substantive decisions like the ones adopted within CSDP). As will be presented in the next chapter, the EU authorities adopted a number of normative acts during the migration crisis, replacing the CSDP system.

\subsection{CSDP characteristics as the Model variables}

As a key reference model of this paper, author identified CSDP change-related variables, which represent an analytical tool for simulating its dynamics. The following variables can also serve as a measurable indicator of the change in the basic CSDP characteristics in relation to extremist events in Europe between 2013 and 2017. The values on which the existence and CSDP functioning are based are the values on which the European Union rests as such: the rule of law, respect

\footnotetext{
${ }^{37}$ About the CSDP, EEAS, available at: https://eeas.europa.eu/topics/common-security-anddefence-policy-csdp_en, accessed on: 11.06.2018

${ }^{38}$ Ibid.

${ }^{39}$ Senge, P. M., \& Forrester, J. W., "Tests for building confidence in system dynamics models", System dynamics, TIMS studies in management sciences, 1980, 14, 209-228
} 
for human rights, democracy, idea of federalism, and justice. The standards on the functioning of CSDP are regulated by the acts on the organization of work and activities of each Directorate-General, but also of the European Commission as a whole. Standards also concern the direct action of European Union soldiers and experts on the ground in civilian missions and military operations. ${ }^{40}$ Principles in the daily operation of CSDP institutions and organizational units are openness, publicity/transparency, equal representation of Member States, professionalism in work, continuous control of system parts, hierarchical subordination of system parts and continuous evaluation. ${ }^{41}$ This policy is an extremely adaptable system, and at the same time determined by external factors. In the presented analytical matrix, CSDP is a system that is adapted to the needs of forced migration in both regions at the same time. In the MENA region, through permanent diplomatic, civilian and military presence (civilian missions and military operations), while on the other, within Europe, it adapts itself to social problems and potential extremist behavior of immigrants. However, according to many authors, CSDP is characterized by relatively slow adaptability, caused by the specificity of the decision-making process in the assembly bodies and committees. ${ }^{42}$ Also, this system is determined by external factors from different aspects; from the bottom up, because the system is managed and made by Member States, and on the other hand, it adapts to global geopolitical realities, but also responds to current crises outside EU territory. These three determinants of the system relate to its behaviour in relation to the external environment. On the basis of the theoretical points of view, and then the recognized migratory factors, variables that can be used in the software simulation of the CSDP model of functioning and development are proposed.

Scheme 4: Causal diagram of reverse de-radicalisation ${ }^{43}$

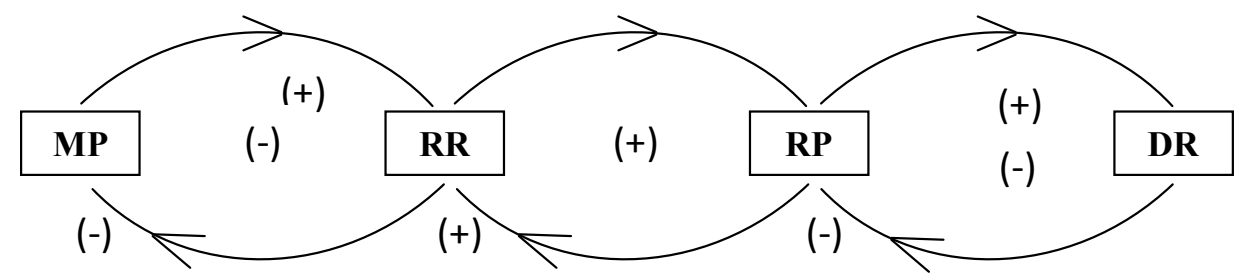

Source: Author, adapted scheme

${ }^{40}$ Ibid.

${ }^{41}$ Ibid.

${ }^{42}$ Sriskandarajah, Dhananjayan, Laurence Cooley, and Howard Reed, "Paying their way: The fiscal contribution of immigrants in the UK", Institute for Public Policy Research, London, 2005.

${ }^{43}$ Whereas: MP - migratory population; RR - radicalisation ratio; RP - radicalised part of population; DR - deradicalisation ratio; 
The causal diagram of the de-radicalisation shows the dynamics of the rate of radicalization, according to which it is lower if the positive feedback is less than negative, since the number of those de-radicalised is increased at the expense of those who have already been radicalized. A larger migratory population can potentially cause a higher rate of radicalization, which consequently leads to a larger population that is radicalized. The greater the rate of de-radicalisation, the rate is reversing, and the reduced radicalized population leads to a reduction in the rate of radicalization which reflects on the migratory population.

Equation 1: Population under the extremism risk

$$
\mathrm{EP}=\zeta \times \mathrm{K} \times \mathrm{MP} \times \frac{\mathrm{EP}}{\mathrm{MP}}
$$

The likelihood of extremism implies the likelihood that a person will conduct an extremist act after learning that a similar act has already been carried out, and in most cases not being sanctioned by the official judicial authorities.

Scheme 5. Analytical matrix of variables

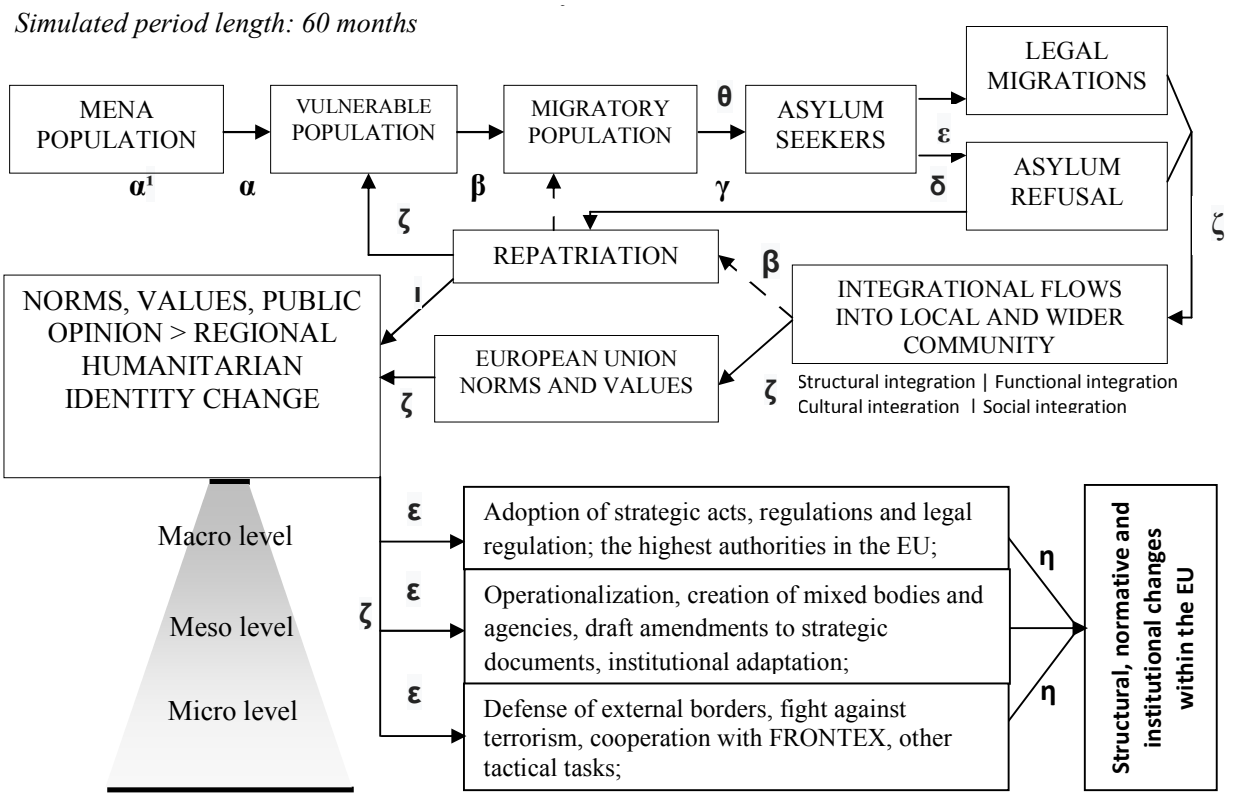

INTERACTION INTENSITY

Source: Author 
In this sense, it is possible to express mathematically the rate of extremism, which is equal to the combination of factors (the total number of migrants exposed to the risk of extremism) multiplied by the likelihood of those with whom they come into contact to radicalize. ${ }^{44}$

There are a number of factors that make up the rate of radicalization in the overall migratory population, and in this way the effects of the CSDP on the internal plan result in de-radicalisation of the mentioned population. If the positive relationship is less than negative, the number of those who are de-radicalized will increase at the expense of those who have already been radicalized. The same applies to the duration of exposure due to the failure of the crisis. Then the weaker the negative reverse flow is, it will affect weaker radicalization and the more likely the extremist act will be. The geographical distribution of conflicts $(\alpha)$ is a precondition that determines the vulnerable population of the MENA region. In addition to the purely geographical criteria, the intensity of the conflict as well as the number of victims is extremely important. ${ }^{45} \mathrm{~A}$ certain part of the emigrating population establishes a migratory population with an important variable $(\beta)$ that relates to pull factors such as normative-democratic "regional humanitarian identity" and "forced quality" living conditions in Europe. On their route towards Western Europe, migrants face various obstacles $(\gamma)$ such as frequent changes in national legal regulations, border closures, conflicts with local populations, environmental pollution, etc. Once established in the country of its ultimate destination $(\delta)$, they face uncertainty about (non) granting asylum/residence $(\varepsilon, \eta)$ and indirectly confronting decisions made by the highest authorities of the Union. In a certain number of cases, immigrants confront the local population $(\zeta)$ and create the perception of individual risks in terms of their own security $(\theta)$. The immigrants, according to the proposed model, are stimulating factors of the conducted violent acts ( 1 ). In this way, the combined effect of a number of factors (variables) on immigrant groups creates a feeling of frustration that can lead to sociopathological forms of behaviour, and consequently to extremist acts. Such actions lead, on a strategic, operational and tactical plan, to structural changes in the CSDP, which will be discussed.

\footnotetext{
${ }^{44}$ Whereas EP stands for population under the extremism risk, $\zeta$ - radicalisation ratio, $\mathrm{K}$ extremism development possibility, and MP - migratory population.

${ }^{45}$ Regarding this variable, it is also important to point out the objective economic difficulties that occur in the MENA region, and which are an important factor that contributes to the decision of immigrants to leave a certain area.
} 
Table 4. Variables index

\begin{tabular}{|c|c|c|}
\hline & Variable & Variable variances \\
\hline$\alpha$ & $\begin{array}{l}\text { Geographical dispersion of conflict } \\
\boldsymbol{\alpha}^{\mathbf{1}} \text { Economic difficulties in MENA }\end{array}$ & $\begin{array}{l}\text { - Conflict intensity and casualties } \\
\text { - Geographical criterion }\end{array}$ \\
\hline$\beta$ & \multicolumn{2}{|l|}{ Pull factors (Massey et al.) } \\
\hline$\gamma$ & Migrant route, legal barriers & $\begin{array}{l}\text { - Frequent regulatory changes } \\
\text { - Attacks on the local population } \\
\text { - Environmental problems }\end{array}$ \\
\hline$\delta$ & \multicolumn{2}{|l|}{ Settlement into the reception country } \\
\hline$\varepsilon$ & $\begin{array}{l}\text { Policies of Member States, suprana- } \\
\text { tional decisions, asylum refusal }\end{array}$ & $\begin{array}{l}\boldsymbol{\eta} \text { - CSDP Normative change, institutional } \\
\text { structure establishment, new tasks }\end{array}$ \\
\hline$\zeta^{46}$ & $\begin{array}{l}\text { Extremism, radicalization, and other } \\
\text { sociopathological activities }\end{array}$ & $\begin{array}{l}\text { - Disappointment of migrants by treatment } \\
\text { of the local population } \\
\text { - Terrorist acts }\end{array}$ \\
\hline$\theta$ & Risks perception & - Uncertainty regarding the final outcome \\
\hline 1 & $\begin{array}{l}\text { Conducted extremism acts factor } \\
\text { (Nazli Choucri et al.) }\end{array}$ & Contact with local population \\
\hline$\kappa$ & \multicolumn{2}{|l|}{ Extremism possibility index } \\
\hline$\lambda$ & \multicolumn{2}{|c|}{ Deradicalisation measurement (deradicalisation feedback diagram) } \\
\hline
\end{tabular}

\section{DISCUSSION: CSDP IN SUI GENERIS CIRCUMSTANCES}

According to the Society for System Dynamics, each system (and especially one characterized by a complex political network of interconnections) is distinguished by the so-called "Systemic behaviour". ${ }^{47}$ Based on Scheme 4 and Scheme 5 , it can be concluded that the behaviour of a system such as the EU CSDP depends to a large extent on the will of the Member States who make it, but also on the challenges of an external type (crises, wars, natural hazards) all other socio-political factors that the EU CSDP interacts with. ${ }^{48}$

${ }^{46}$ This variable signifies extremist behavior on the territory of Europe in the analyzed period. Over 40 terrorist acts carried out, and much more extremist activities of lower intensity were recorded in the period between 2013 and 2017. Although the trend of the total number of attacks declined (in 2014 it was 226, 2015 in total 193, while in 2016 - 142), the total number of victims and injured persons is measured by thousands. The number of people arrested is also declining, with the exception of France, while the average sentence imposed in the United Kingdom is 27 years in prison. It is also interesting that in France, the average sentence was only 7 years, and the number of court trials was led in 580 cases in 2016 and 2017 (Europol, 2017).

${ }^{47}$ More information about the Society and its publication available at the following link: https://www.systemdynamics.org (Accessed on: 06.03.2018. 13:23)

${ }^{48}$ Evaluation of the EU CSDP is possible through the quarterly and annual reports submitted by the European Commission to the European Parliament. In addition to these, there are extraor- 
In this regard, this paper offered an analysis of the key variables and factors that influence the functioning and development of this sui generis policy in the case of migration that took place between 2013 and 2017, and then a review of the potential internal change of CSDP, followed by the development of a series of extremist events in Europe in the same period. Although in earlier academic conceptualizations, there were efforts to avoid the link between extremism as a form of sociopathological phenomena and CSDP, ${ }^{49}$ current developments in the past five years, normative changes, but also the reform of institutional structures, disprove such claims. Writing about the possible causes of the lack of CSDP's deployment in countering extremism, Bruno Oliviera Martins sublimates them into several categories: the lack of consensus among Member States, the weakness of the EU as a supranational organization, and different views on CSDP capacities. ${ }^{50}$ He further refines his view that the CSDP can act against extremism in the territory of Europe only in the event of "disturbing the vital democratic values on which it rests", ${ }^{51}$ and includes strategic documents, but also the principle of "act locally, exist globally" in analysis. ${ }^{52}$ The break point in model simulation is the results of integration (functional and social), of which the further fate of individuals and immigrant groups depends on. A similar model of radicalization presented by Erik Pruyt \& John Kwakkel is based on the principle of persuading members of the community in relation to a particular issue, where it is irrelevant where the mentioned conviction comes from. The central outcome of this model is the existence of a "frustration of a certain part of the population" which is convinced that some social change is wrong, ${ }^{53}$ and in a return coupling that occurs between a part of a population that is not convinced.

In the model (Scheme 6) illustrated in this paper, such feelings of immigrants appear at the moment of a Member State's refusal of asylum (variable " $\varepsilon$ ") and the initiation of the repatriation process, while at a lower, more direct level such frustration occurs in the event of failure to integrate (functionally, and then socially)

dinary reports submitted by the High Representative for Foreign Affairs and Security Policy to the European Commission and the European Council. Although the reports are predominantly descriptive and qualitative, they can still quantify indicators of the success of security and defense policy. It is very important to provide an answer to the question of which CSDP elements are most relevant to the change due to the operation of an integral group of factors.

${ }^{49}$ Meyer, C., "The purpose and pitfalls of Constructivist forecasting: Insights from strategic culture research for the European Union's evolution as a military power", International studies quarterly, 2011, 55(3)

${ }^{50}$ Bruno Oliveira Martins \& Laura C. Ferreira-Pereira, "Stepping inside? CSDP missions and EU counter-terrorism”, European Security, 2012

${ }^{51}$ Ibid., p.17

${ }^{52}$ Ibid.

${ }^{53}$ Pruyt, E. \& Kwakkel, J., "Radicalization under deep uncertainty: a multi-model exploration of activism, extremism, and terrorism", System Dynamics Review, 2014 
in the community. In the later developed model by Pruyt, ${ }^{54}$ extremist behaviour arises as the outcome of a long-lasting gradual process. A part of the population, unhappy with its acceptance within its community, is convinced that it is discriminated and in that way gradually forms its position regarding the way it wants to contribute to change. However, Pruyt assumes that this part of the population becomes marginalized by the deepening of the crisis, and thus creates frustration that in the long run leads to extremist acts. ${ }^{55}$ The model offered in this paper points to the relative longevity of the simulated process - the migratory crisis. In five years simulation length, there are many events and phenomena that have (indirectly) provoked antipathies for immigrants on the European continent. The last model important for this discussion is that developed by Choukri and associates. ${ }^{56}$ This model presupposes the effect of conducted extremist events on future ones, and emphasizes the "motivating" significance of creating the extrusion of a certain part of the population, caused by the effects of the previous acts. The model in this paper points to repatriation as a turning point in relation to the new variable. Namely, if immigrants perceive repatriation as an exclusively hostile act, the radicalization of their behaviour can be enhanced by awareness of the "positive effects" of extremist acts committed on the territory of Europe. Accordingly, the exposed mathematical formula for the likelihood of the emergence of extremism must be supplemented by additional relationships between variables, ${ }^{57}$ which affect the systemic dynamics of this policy.

Equation 2: Likelihood of the emergence of extremism

$$
\operatorname{CSDP} \boldsymbol{\eta}=\frac{\gamma+\delta+\left(\lambda \times \frac{\zeta}{K}\right) \times\left(\zeta \times K \times U M P \times \frac{E P}{M P}\right)}{\varepsilon}
$$

Institutional and normative systemic dynamics (and changes) of CSDP can be understood as the ratio of products of "previous" factors (migratory route, residence, probability of extreme and radicalization) and populism extreme (EP), and the interests of Member States, or supranational decisions related to with the stated factors. The interests of the Member States act on the change in the CSDP in the opposite direction in relation to the listed factors listed in the numerator of

\footnotetext{
${ }^{54}$ Pruyt, Erik, "Small system dynamics models for big issues: Triple jump towards real-world complexity", Complex World, 2013, 39(3)

${ }^{55}$ Ibid.

${ }^{56}$ Choucri N. et al., "Using system dynamics to model and better understand state stability", 2007, Working Paper 4661-07, Available at: https://dspace.mit.edu/bitstream/handle/1721.1/39650/4661-07.pdf?sequence=1, MIT Sloan School of Management, Massachusetts Institute of Technology, Cambridge, MA.

${ }^{57}$ See Table 4.
} 
the equation. In all three comparative cases, as well as in the model presented in Scheme 6 , the regional humanitarian identity from bottom to bottom is gradually changing, from public opinion to pressure on the policies of national governments, and consequently the EU institution to react first on the normative plan, radicalization asylum policies, a more robust border control, and then at the structural-institutional level, by establishing new bodies and organs. Paradoxically, but slowly, by creating specific public opinion views on the issue of immigrants, European leaders have proposed rigorous reforms of the CSDP, or greater Union assertiveness in helping the national police services in maintaining the borders of illegal crossings.

This has led to innumerable changes to acts, institutional structures, the creation of new bodies and agencies, and even the integration of competencies with the police forces of the Member States. Environment change, but also within the Union itself in relation to immigrants led to a gradual change in its supranational policies. Thus, the European Union adopted its Global Strategy in 2016, which explicitly cited the Union's readiness to strengthen its southern and eastern member states through the development of "more effective migration policies and practices". ${ }^{58}$ The interaction of the elements of the CSDP system increases further from the macro to the micro level. The pyramidal institutional organization and the structure of the elements made it possible exactly this outcome.

\section{CONCLUDING REMARKS}

This article has demonstrated the possibility of Common Security and Defense Policy inclusion in the analytical framework and context of migration movements from the MENA region to Europe. Based on the review of the most significant theoretical debates, key variables have been identified for the analysis of CSDP's functioning and development, which are not inherent in other subsystems within the institutional structure of the European Union. The central thesis of this paper was to determine the prognostic validity of the theoretical concept of regional humanitarian identity. Changing the collective norms and values, as well as individual attitudes toward newly-coming immigrants, indirectly changes the CSDP nature. At the beginning of 2016, a new supranational policy of "integrated approach to conflicts and crises" was adopted, which paved a new way of involving national contingents in CSDP operations on the ground. ${ }^{59}$ Observed from the aspect of temporal and spatial activities of this policy, these are definitely crises

\footnotetext{
${ }^{58}$ An integral EU Global Strategy text is available at: http://eeas.europa.eu/archives/docs/ top_stories/pdf/eugs_review_web.pdf(Accessed on: 13.06.2018. 15:34)

${ }^{59}$ The European External Action Service, 2018, https://eeas.europa.eu/headquarters/headquarters-homepage/area/security-and-defence_en (Accessed on: 4.4.2018. 14:43)
} 
management operations that occur at the very beginning of the crisis focus (in certain cases pre-mediation), in area where the conflict is taking place. This process is not final or unilateral; on the contrary, the rational elements of CSDP can be implemented in various phases of events and crises. The simulation of the variables in the model presented in this article and its comparison with the so far known models demonstrated the confirmation of the assumption about the causeand-effect relationship between the intensification of extremist acts and the structural changes of the CSDP. The migratory crisis, and the culminating waves of extremism that took place between 2013 and 2017, undoubtedly contributed to the change of regional humanitarian identity, thereby indirectly changing the legislative and institutional settings on which the CSDP rests. The so-called frustration with the treatment of destination states, provoke migrants' desire for extremist forms of action, which can be caused by gradual spiral development of negative events concerning their status, or they can be motivated by previous extremist acts, of which CSDP is not isolated. Interaction among CSDP elements is intensified by lowering to lower institutional levels, while supranationality of the system embodied in the fact that it consists of representatives of 27 Member States. This system is in its process of creation, that is, its full integration has not yet been completed. Therefore, it is very important that Marry Kritz and Hane Zlotnik conclude that the analysis of modern international migrations imposes the need for a systemic approach, ie a dynamic perspective of study - from recognition to a detailed insight into changing trends and forms of contemporary migration movements in the world. ${ }^{60}$

Consideration of the causes or consequences of international migrations, either from the perspective of the countries of origin or reception, often fails to explain the dynamics associated with the development of migration movements as a process. ${ }^{61}$ The findings of this paper indicate the ability of CSDP to adapt and change. The management of complex regimes, such as Ghering and Fod named CSDP, ${ }^{62}$ proved to be extremely uncertain, due to the huge number of variables that alter their course of action, but also because of the nucleus of the migratory crisis. The future academic endeavours in the radicalization examination should move in the direction of simulating the offered model in this paper. Model simulation should answer the question of how the migratory population is radicalized, i.e. under whose influence, at the speed and intensity, which can be the basis for

\footnotetext{
${ }^{60}$ Kritz, Mary \& Hania Zlotnik, "Global interactions: migration systems processes and policies", Clarendon Press Oxford, 1992, 1-16.

${ }^{61}$ Predojević-Despić, Jelena, "Ka razumevanju determinanti međunarodnih migracija danasteorijska perspektiva”, Stanovništvo, 2010, 48/1.

${ }^{62}$ Gehring, Thomas and Benjamin Faude, "The dynamics of regime complexes: Microfoundations and systemic effects", Global Governance: A Review of Multilateralism and International Organizations, 2013, 19, no. 1, 119-130
} 
the decision makers in terms of a comprehensive approach to a particular problem. At this level, it is impossible to derive a prediction of how the European Union will develop in security and defense capacity. It is clear theoretical settings of international relations, and safety studies as a sub discipline, significantly determine further analysis of these phenomena, however, it is not possible to circumvent the systemic approach in analyzing the interaction between elements, as well as external factors contributing to CSDP functioning. Hence the dynamics of complex regimes, as an adequate theoretical foundation for the study of CSDP, is one of the recommended ways of researching security and defense integration at the supranational level. In the end, it is important to point out the existence of significant interdisciplinarity in the study of the links between migratory movements and CSDP as a type of system. Therefore, in further academic efforts to examine the change of such a complex policy, it is necessary to apply different disciplinary approaches that include sociological, political, historical and legal aspects.

\section{REFERENCES}

Bruno Oliveira Martins \& Laura C. Ferreira-Pereira, "Stepping inside? CSDP missions and EU counter-terrorism", European Security, 2012, 21:4, 537-556

Choucri N. et al., "Using system dynamics to model and better understand state stability", 2007, Working Paper 4661-07, Доступно на: https://dspace.mit.edu/ bitstream/handle/1721.1/39650/4661-07.pdf?sequence=1, MIT Sloan School of Management, Massachusetts Institute of Technology, Cambridge, MA.

De Haas, H., "The myth of invasion: The inconvenient realities of African migration to Europe", Third world quarterly, 2008, 29(7), 1305-1322.

Europol, (2017). EU Terrorism Situation and Trend Report 2017. The Hague: Europol, ISBN 978-92-95200-79-1.

Forrester, J. "System dynamics, systems thinking, and soft OR", System dynamics

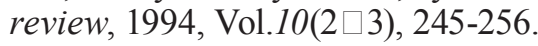

Gehring, Thomas and Benjamin Faude, "The dynamics of regime complexes: Microfoundations and systemic effects", Global Governance: A Review of Multilateralism and International Organizations, 2013, 19, no. 1, 119-130.

Global Strategy of the European Union, Official EU Journal, Brussels, 2016.

H. Sjursen, "The EU as a 'Normative' Power: How Can this be?", Journal of European Public Policy, 2005, Vol.13, No.2.

Heckman, F., "National modes of immigrant integration", Comparative European Research in Migration, Diversity and Identities University of Duesto: Bilbao, 2005, 99-112.

Heckman, Friedrich, "National modes of immigrant integration", Comparative European Research in Migration, Diversity and Identities University of Duesto, Bilbao, 2005

Ian Manners, Normative Power Europe: A Contradiction in Terms?, 2002, Journal of Common Market Studies,Vol.40, No.2 
Kritz, Mary \& Hania Zlotnik, "Global interactions: migration systems processes and policies", Clarendon Press Oxford, 1992, 1-16.

Lee, Evans, "A theory of migration", Demography, 1966, 3(1), p.47-57.

Massey, Douglas S., Joaquin Arango, Graeme Hugo, Ali Kouaouci, Adela Pellegrino, and J. Edward Taylor, "Theories of international migration: A review and appraisal", Population and development review, 1993, pp.431-466.

Meyer, C., "The purpose and pitfalls of Constructivist forecasting: Insights from strategic culture research for the European Union's evolution as a military power", International studies quarterly, 2011, 55(3), 669-690.

Newman, Edward, "The Limits of Liberal Humanitarianism in Europe: The 'Responsibility to Protect'and Forced Migration", European Review of International Studies, 2018.

Ninković V. et al., "Dynamic Migration Flow Modeling”, Security Dialogues, Vol 8, No.1-2. Skopje: St. Cyril and Methodius University, pp.149-169

Parkins, N., "Push and pull factors of migration", American Review of Political Economy, 2010, 8(2), 6.

Predojević-Despić, Jelena, "Ka razumevanju determinanti međunarodnih migracija danas-teorijska perspektiva", Stanovništvo, 2010, 48/1, str.25-48.

Pruyt, E. \& Kwakkel, J., "Radicalization under deep uncertainty: a multi-model exploration of activism, extremism, and terrorism", System Dynamics Review, 2014, 30(1-2), 1-28.

Pruyt, Erik, "Small system dynamics models for big issues: Triple jump towards realworld complexity", Complex World, 2013, 39(3)

Schoorl, Heering et al., "Push and pull factors of international migration: a comparative report", European Communities, Luxembourg, 2000.

Schoorl, J., Heering, L., Esveldt, I., Groenewold, G., \& Van der Erf, R. (2000). Push and pull factors of international migration: a comparative report. Luxembourg: European Communities

Senge, P. M., \& Forrester, J. W., "Tests for building confidence in system dynamics models", System dynamics, TIMS studies in management sciences, 1980, 14, 209-228.

Sriskandarajah, Dhananjayan, Laurence Cooley, and Howard Reed, "Paying their way: The fiscal contribution of immigrants in the UK", Institute for Public Policy Research, London, 2005.

Stekić N., "Nadnacionalne bezbednosne i odbrambene integracije u studijama bezbednosti na primeru Zajedničke bezbednosne i odbrambene politike Evropske unije", Master rad, Beograd: Fakultet bezbednosti

System Dynamics Society, https://www.systemdynamics.org/ (Приступљено 06.03.2018. 13:23)

The Global Refugee Crisis, Region by Region”. The New York Times. 26 August 2015. Weiler Kathleen, European constitutionalism beyond the state, Cambridge University Press, 2003.

Zarate, M. A., Garcia, B., Garza, A. A., \& Hitlan, R. T. (2004). Cultural threat and perceived realistic group conflict as dual predictors of prejudice. Journal of experimental social psychology, 40(1), 99-105. 
Zincone, Giovanna \& Tiziana Caponio, "The Multilevel Governance of Migration", The Dynamics of International Migration and Settlement in Europe, 2006, p.269. European External Action Service, https://eeas.europa.eu/headquarters/headquartershomepage/area/security-and-defence_en (Приступљено 4.4.2018. 14:43)

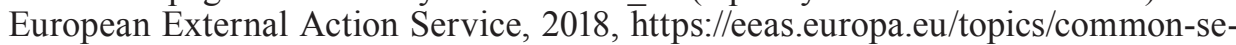
curity-and-defence-policy-csdp_en, 11.06.2018. 11:23 
Ненад 3. Сиеекић, исиираживач ирииравник Инстиийуй за међународну йолитиику и иривреду nenad.stekic@diplomacy.bg.ac.rs

\section{Екстремизам као чинилац системске динамике Заједничке безбедносне и одбрамбене политике Европске уније током миграторне кризе}

Сажетйак: Циљ овог̄ рада јестие ексииликаџија међуодноса ирромене

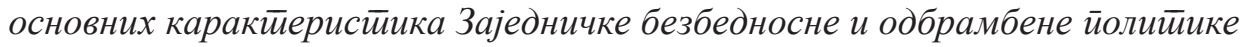
Евройске уније као референйног̄ објекӣа у односу на иетиогоодищњи иррилив миг̄ранайа у Евройску унију у иеериоду између 2013. и 2017. г̄oдине. Ауйор

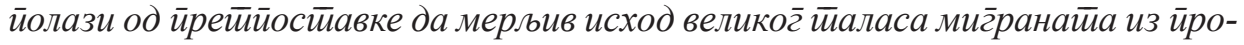
стиора Блиског̄ Истиока и Северне Африке у Евройу, као и йојаве йойуй йе-

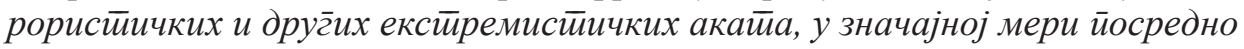
уйичу и мењају иррироду ове наднационалне безбедносне йолитиике. На бази иееоријских дебат̄а у вези са ирисилним мигррацијама, аут̄ор је користиио

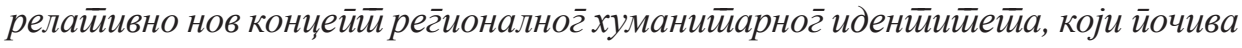
на йринцийу норми и вредносйи на којима се заснива йостиојағе одређене државе или груйе држава, а које су државе домаћини за имиграниее. Свеукуйно деловање йоделеменайа регіиона - држава, юихових инстиийуција, али и гррађана, условљено је иниеерним нормама које насйају као йоследица иира-

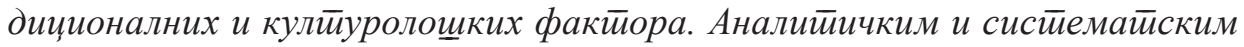

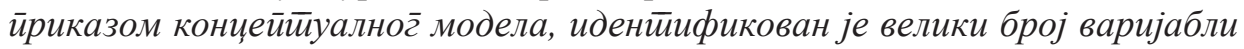
чији међуодноси значајно уйичу на функсионисање комйлексног систиема каква је наведена йолитиика Евройске уније. Применом сисиемске динамике

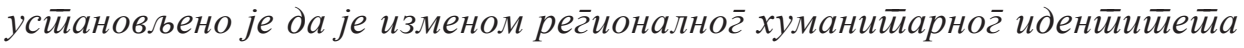

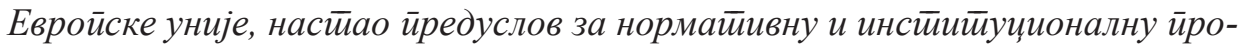
мену Заједничке безбедносне и одбрамбене йолийике.

Кључне речи: Евройска унија, ЗБОП, рег̄ионални хуманийарни иденӣи-

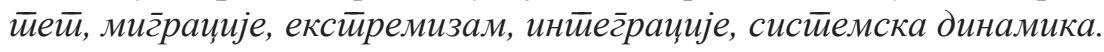

Датум пријема рада: 09.09.2018. 